\title{
Two Stages to the Current Recession
}

\author{
NORMAN N. BOWSIIER
}

$T_{1}$

HE pattern of economic developments since the fall of 1973 has seemed baffing to many. It has been a period of prolonged and deep economic recession combined with intensified inflation for a year. The recession has had substantially different characteristics from the four previous recessions since 1950 , including two distinct periods within the current contraction.

In terms of causal forces, the recent downtum also differs from earlier contractions. All previous recessions in the past twenty-five years were preceded by periods of pronounced monetary restraint. The current downtum, by contrast, was preceded, and accompanied for a time, by stimulative policy actions. As the downturn progressed, however, the growth of the money stock did slow markedly. In addition, developments which have hampered production - such as the higher price of oil, unfavorable weather conditions, and the effects of price controls - have played a much greater role in the current downtum than in earlier recessions.

This article reviews economic developments since the fall of 1973 and finds that some of the confusion concerning the current recession is eliminated if the period is divided into two stages. The first stage, which began in the late fall of 1973, was largely a response to constraints placed on aggregate supply. The second stage, which began in the early fall of 1974 , reflected, in addition, a reduction in the growth of demand for goods and services.

For this study, November 1973 is used as a tentative peak for the past expansion. ${ }^{1}$ It was the month of greatest industrial production, and in the following three months production dedined. The second stage of the recession is postulated to have begun after September 1974. Industrial production and employment,

There are, of courst, diferences of opinion with respect to the dating of the cyclical peak.

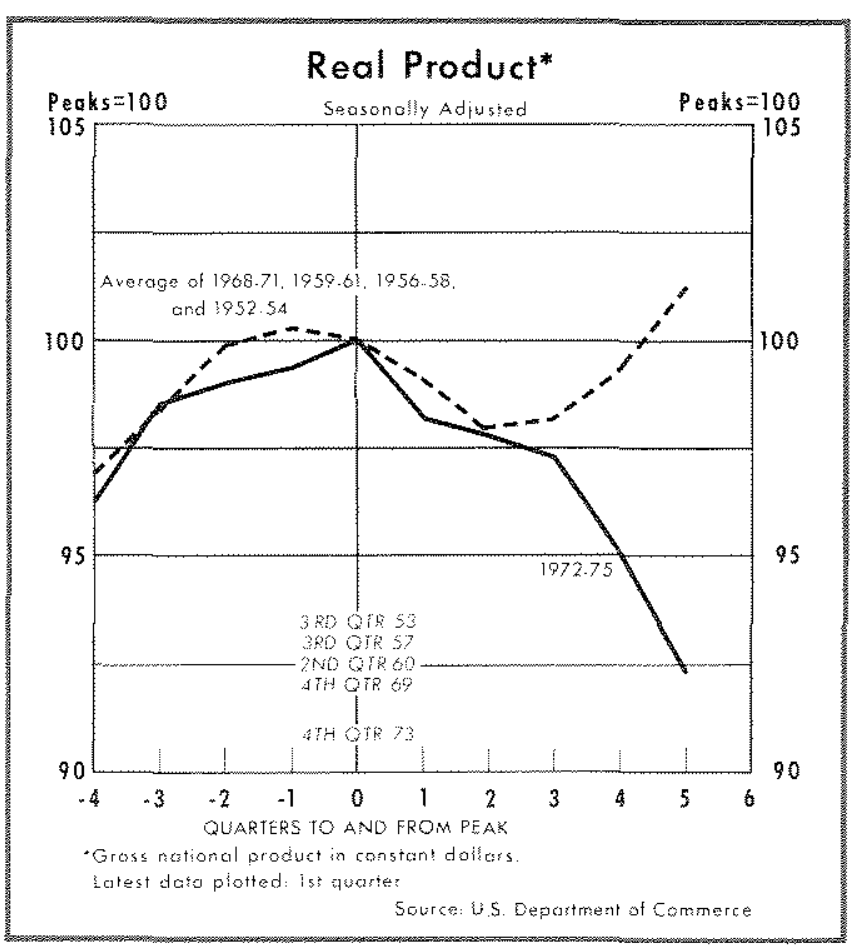

which had risen, on balance, in the previous seven months, declined sharply after September. Comparisons are mate with averages of periods just before and after the four preeding cyclical peaks, as selected by the National Bureau of Economic Research. They are November 1969, May 1960, July 1957, and July 1953.

\section{COURSE OF THE RECESSION}

\section{Produchion}

Total real output of goods and services has declined markedly thronghout the recent economic contraction. In the first five quarters following the peak (ending first quarter 1975), real output decreased at a 6 percent amual rate, and avallable data indicate that 
the contraction probably has continued into the current quarter. By comparison, in the four previous recessions, real output declined for only two quarters, on average, and by the fifth quarter output typically exceeded the previous cyclical high.

Industrial production declined for three months after the 1973 cyclical peak, then increased slightly for the seven months from February to September 1974. During this period, production was bolstered by increased inventory demand as a result of anticipated shortages of many items and by anticipations of inventory profits as prices jumped. However, from September 1974 to April 1975 industrial production again fell sharply at a 21 percent annual rate.

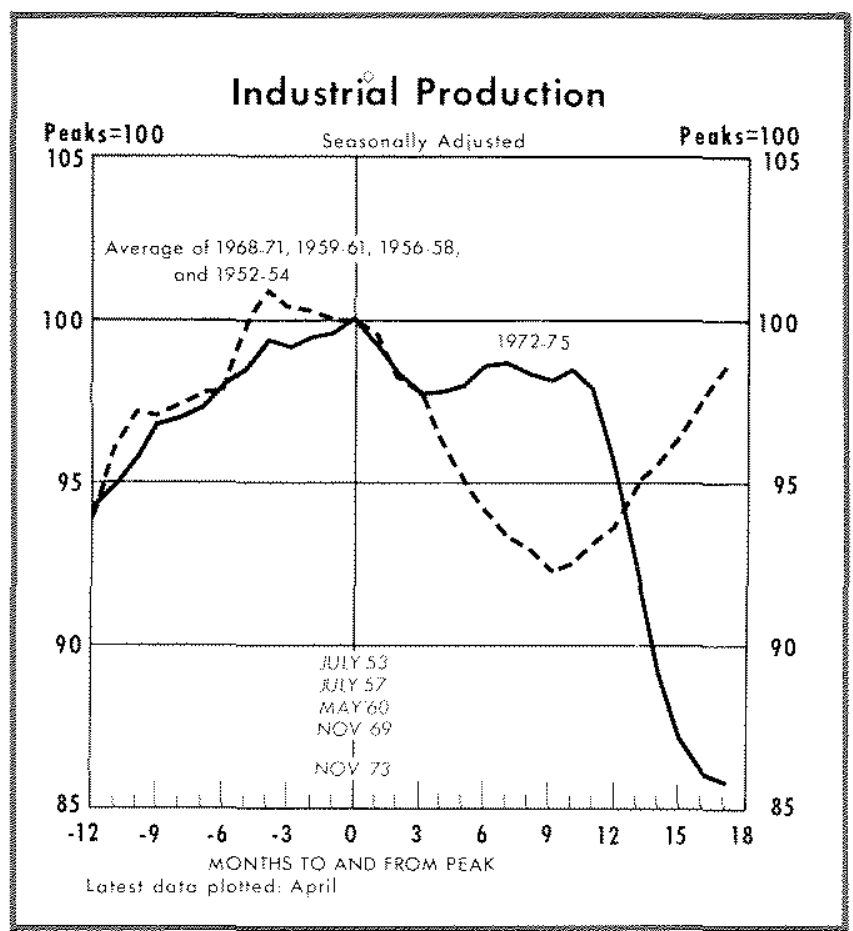

In the four previous recessions the pattern was for industrial production to contract for about nine or ten months. Thereafter, production turned up and rose, on average, at an 11 pereent annual rate from the tenth to the seventeenth month, the stage comparable to the period of marked drop in the current cycle.

\section{Emploument}

A distinctive feature of the current cycle has been the relatively high level of employment throughout much of the contraction. Total employment, which had risen a rapid 4 percent in the year preceding November 1973 , continued to increase, but at a slower 1 percent amnual rate during the first stage of the economic downtum. By contrast, in the corresponding ten-month period of earlier recessions, employment declined at an average 2 percent rate.

Reflecting a marked rise in employment since mid1971, 65.2 percent of the non-institutional population of working force age ( 16 through 64 ) were employed in the third quarter of the current contraction (III/ 1974). On average, 62.7 percent held jobs at the four earlier cyclical highs. As the recession intensified in the period from last September to March, total employment decreased at a rapid 6 percent rate. Nevertheless, 63 percent of the noninstitutional population of working force age were employed in the first quar. ter of 1975, or slightly more than had been employed at the peaks of the four earlier cycles.

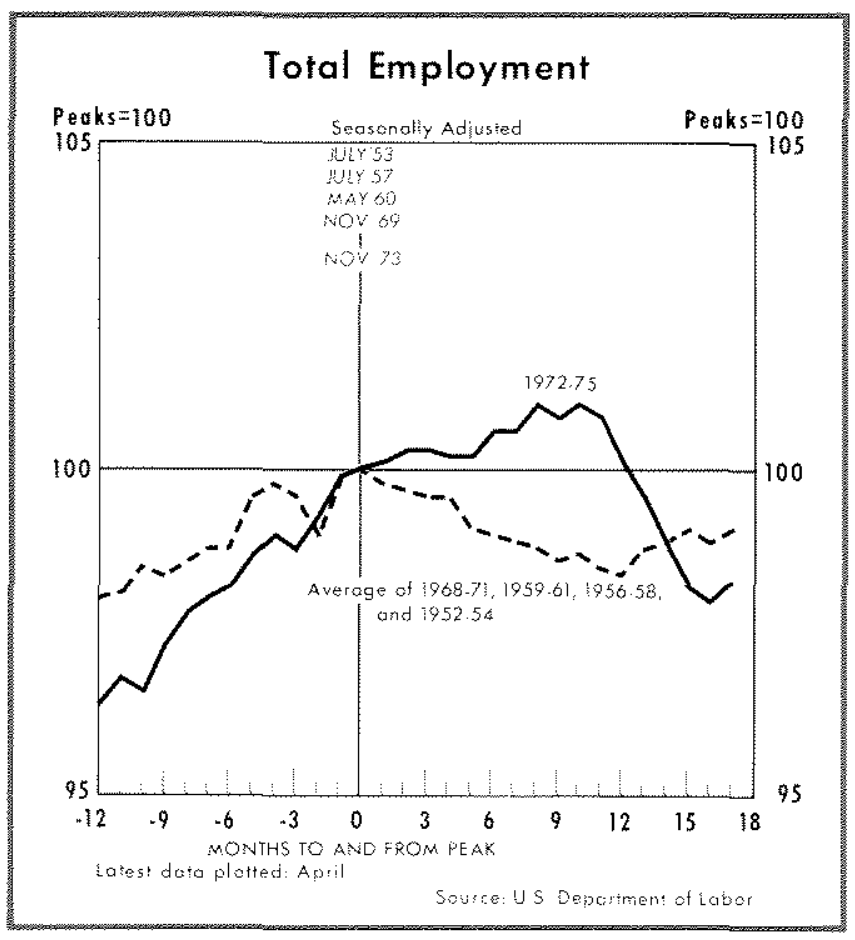

The unemployment rate remained relatively low until early last fall, but has risen abruptly since then. In the first two months after the peak in economic activity, the unemployment rate rose. Then, from the second to the ninth month after the turn (January to August 1974) the unemployment rate changed little, in marked contrast to pronounced increases in comparable periods of the earlier recessions. Since the ninth month, the trends have been reversed; the rate has risen sharply in recent months at a time when it usually remained on a high platean. At the seventeenth month after the turning point (April 1975), the unemployment rate, at 8.9 percent, was higher than in any of the four previous recessions.

The combination of high unemployment and a relatively large percentage of the working age population 


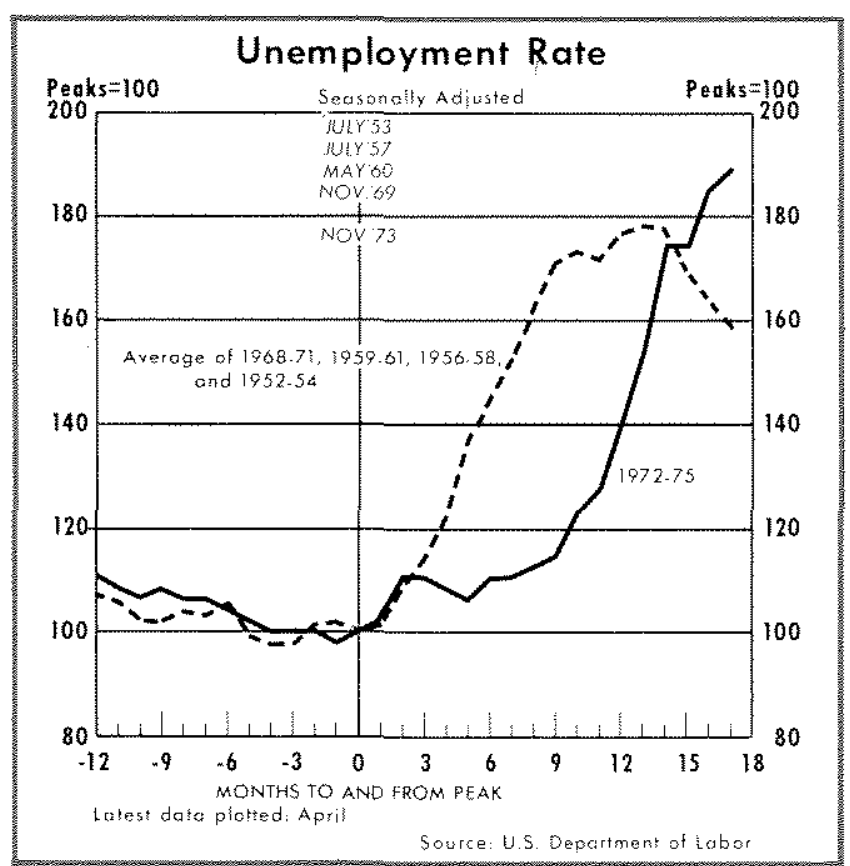

employed reflects a rise in the participation rate in the labor force. A larger share of women have entered the labor force in the last several years, and more recently, second and third members of many households have sought jobs to meet the higher cost of living or to maintain income when another member loses a job.

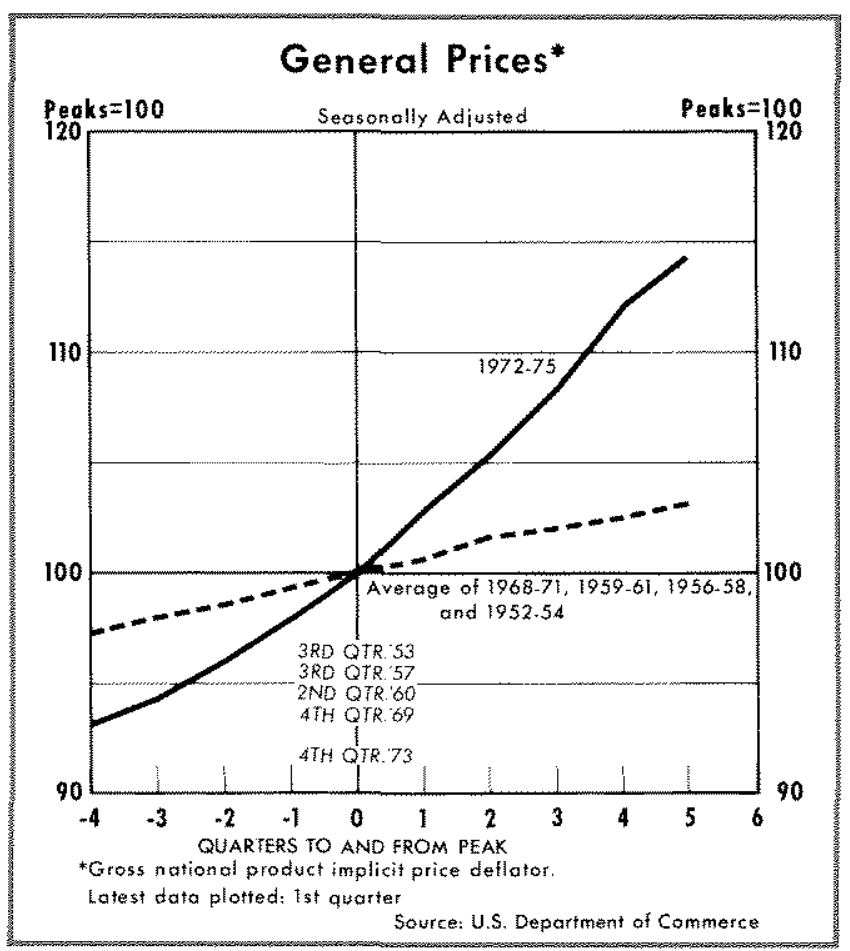

\section{Prices}

The rate of inflation has typically moderated after about two quarters of economic sluggishness. On average, during the final year of the four earlier economic expansions and the first two quarters of retrenchment, general prices, as measured by the implicit GNP deflator, rose at a 3 percent annual rate. From the second to the fifth quarters after the earlier cyclical peaks, overall prices increased at a slower 2 percent average rate.

Despite the sharp and prolonged contraction, the rate of inflation in the most recent downturn did not behave as in previous recessions. For the period from four quarters before to two quarters after the most recent peak, general prices advanced at an 8.5 percent annual rate. From the second to the fifth quarter of the recession, the pace of inflation accelerated to 12 percent. In the fifth quarter, however, prices rose at a slower 8.5 percent pace, and preliminary indications are that the slowing has continued into the sixth quarter (II/1975).

\section{WRST STAGE-NOVTMBEP 1973 TO SETEMBER 1974}

The contraction in production in the current recession, as noted above, has come in two distinct waves - the first from the November 1973 peak to September 1974 and the second from September 1974 to the present. The two periods of decline displayed substantially different characteristics and resulted from different causes. Therefore, in examining the recession it is useful to analyze the two periods separately, even though there is obviously an overlap of causes and effects.

\section{Demand}

Growth in demand for goods and services, as indicated by nominal gross national product, moderated after the 1973 peak, but remained rapid by historical standards for the first three quarters of the recession. From the fourth quarter of 1973 to the third quarter of 1974 , total spending rose at a 7 percent amnual rate. By comparison, even in the final year of economic expansion preceding the four earlier economic contractions, total spending rose at only a 5.5 percent rate on average; then, in the first three quarters of recession the rise in spending slowed to a 0.3 percent rate.

\section{Policy Actons}

The unusual demand growth during the first three quarters of the current recession is partially explained by monetary developments. Monetary actions, as 


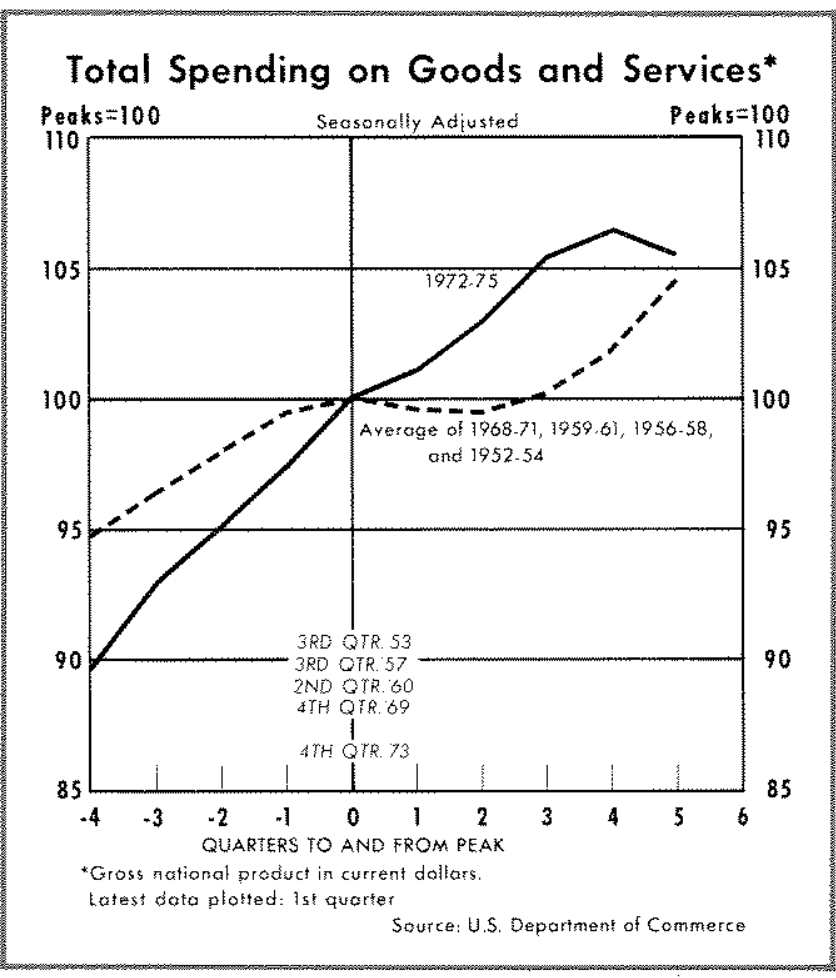

measured by the growth rate of the money stock, were restrictive prior to each of the four earlier business cycle peaks. In each case the rate of money growth fell substantially below its trend rate of growth. This has been cited as a prominent causal factor in the cyclical changes in demand and subsequent recessions. In the year preceding the current recession, the rate of monetary expansion slowed, but fell only slightly below its pre-1973 trend rate of 6 percent in the second half of the year. From the fourth quarter of 1972 to the fourth quarter of 1973 , the money stock rose 6.3 percent.

In the last two quarters of the most recent economic expansion (II/1973 - IV $/ 1973$ ) money growth did slow to a 5.3 percent annual rate. This break in the pace of money expansion probably contributed to the moderation in the growth rate of total spending after the fourth quarter of 1973 .

After the recession began, demand growth continued for a time to be stimulated by monetary expansion. In the first two quarters of the current recession (IV/1973 - II/1974), the money stock grew at a 6.7 percent annual rate, slightly above the trend rate of growth.

Fiscal developments were also more expansive in the first stage of the current recession than in the corresponding periods of earlier recessions. In the year ending third quarter 1974, Federal Govermment ex-

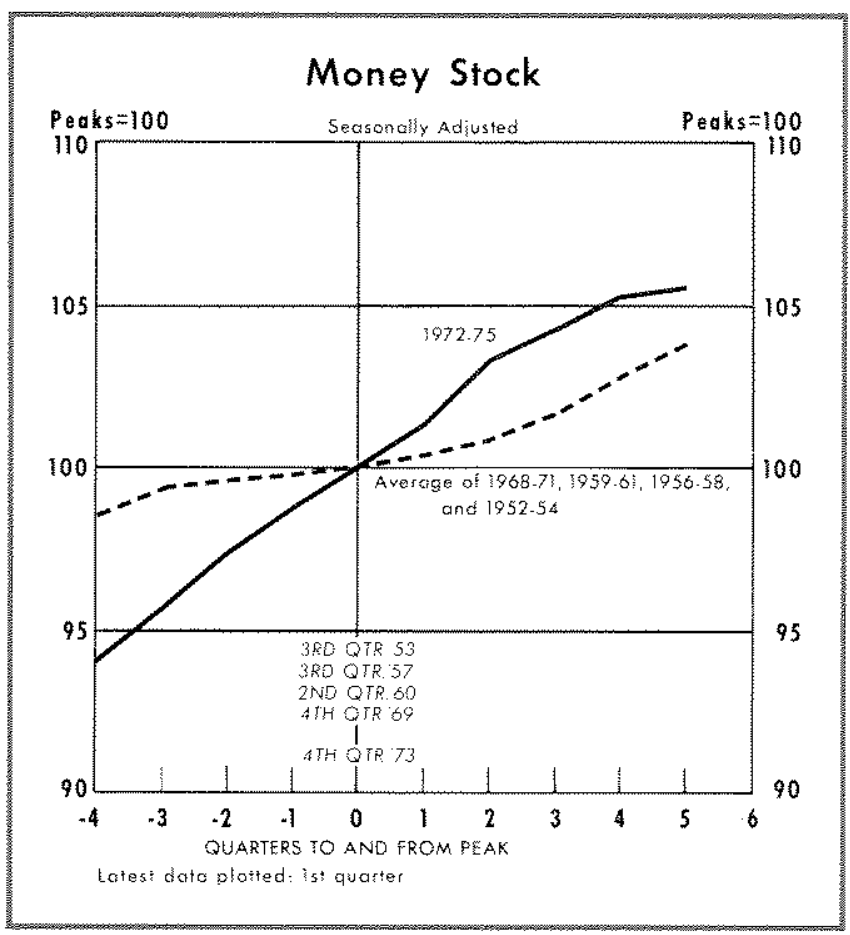

penditures, on a national income accounts basis, jumped 16 percent. In the corresponding spans of the four earlier cycles, Federal spending rose an average of 4 percent.

Even though tax receipts, bolstered by rising nominal incomes, rose sharply, Government expenditures exceeded receipts by a substantial margin in 1973 and 1974. The deficit in the national income accounts budget was $\$ 14$ billion in these two years, compared with an average deficit of $\$ 6$ billion in the corresponding periods of the earlier cycles.

\section{Production}

Despite the relatively rapid growth in demand for goods and services in the first stage of the current recession, output declined. Total real output decreased at a 3.5 percent annual rate from the fourth quarter of 1973 to the third quarter of 1974. In the corresponding periods of the four earlier recessions, output declined at a 2.4 percent rate.

The apparent paradox of substantial production cutbacks in the face of rapidly expanding demand during the first three quarters of the current recession rem flects a number of supply constraints which sharply increased production costs. In 1973, rates of production were very high in many industries, and marginal costs rose rapidly with increased output. Then, the economy was struck by a number of adverse factors which reduced resource availability and raised costs. 
Through monopolistic actions of producing nations and domestic price (and, therefore, production) controls, oil supplies were cut back and energy costs increased sharply. Adverse weather conditions, both here and abroad, resulted in widespread crop failures and increased food prices. Depreciation of the dollar relative to other currencies raised domestic production costs by increasing the dollar prices of imported goods, and caused significant shifts in demand for resources. Compliance with environmental and safety laws consumed resources and added further to costs, while making adjustment to all the other changing forces much more difficult and costly.

In addition, output was inhibited by marked changes in consumer spending and by price controls. The rapidly rising prices of certain items prompted consumers to shift consumption patterns, causing abrupt contractions in the demand for some items (such as autos) while intensifying upward pressures on prices of other commodities. Price controls, still in effect in early 1974, prevented firms from adjusting to increasing production costs. With fixed selling prices, production of many goods was no longer profitable; some marginal facilities were closed, and plant expansions were postponed. As a result, production in related industries was hampered further by shortages for a time, and later by higher prices for inputs.

These interferences in the productive process made the country poorer by reducing output capabilities. The adverse effects of these constraints were distributed through the economy by higher prices, a chief factor in the intensification of inflation during a period of recession.

\section{SECOND STAGE-SETTEMDER I974 TO DATE}

\section{Demand}

As the effects of some of the supply interferences were diminishing last fall, production was severely hampered a second time by a marked slowing in demand for goods and services. Total spending, which had risen at a 7 percent annual rate in the first three quarters of the recession, decelerated sharply last fall and declined in the first quarter of this year. By comparison, in the four previous recessions spending rose at an average 0.3 percent rate in the first three quarters, but at an accelerated 9 percent rate in the fourth and fifth quarters. With the reduction in demand growth, it was not feasible to maintain existing production levels, and sharp cutbacks occurred.
The money stock, after rising at a 6.7 percent annual rate in the first two quarters of the recession, slowed abruptly to a 3 percent pace in the following three quarters (ending March 1975). In the earlier recessions money typically increased at an accelerated rate in the third through fifth quarters. A few months after money began accelerating in previous recessions, growth in demand also accelerated. A few months after money growth began decelerating during the current recession, growth in demand also decelerated.

The first stage of the current recession, being caused in large part by constraints on supply, was unlike any of the earlier recessions, which were largely demand induced. However, the second stage, which has been fostered by a slowing in the growth of demand, is similar to the earlier experiences. Hence, for certain studies, comparisons of the period since last September with the periods immediately following the previous cyclical peaks have more relevance than comparisons which use the entire span of the current recession.

At this second stage turning point, the growth rate in total demand for goods and services fell precipitously from the aforementioned 7 percent rate in the first stage to the virtual plateau in the first two quarters of the second stage. Between the comparable periods before and after the four earlier cyclical

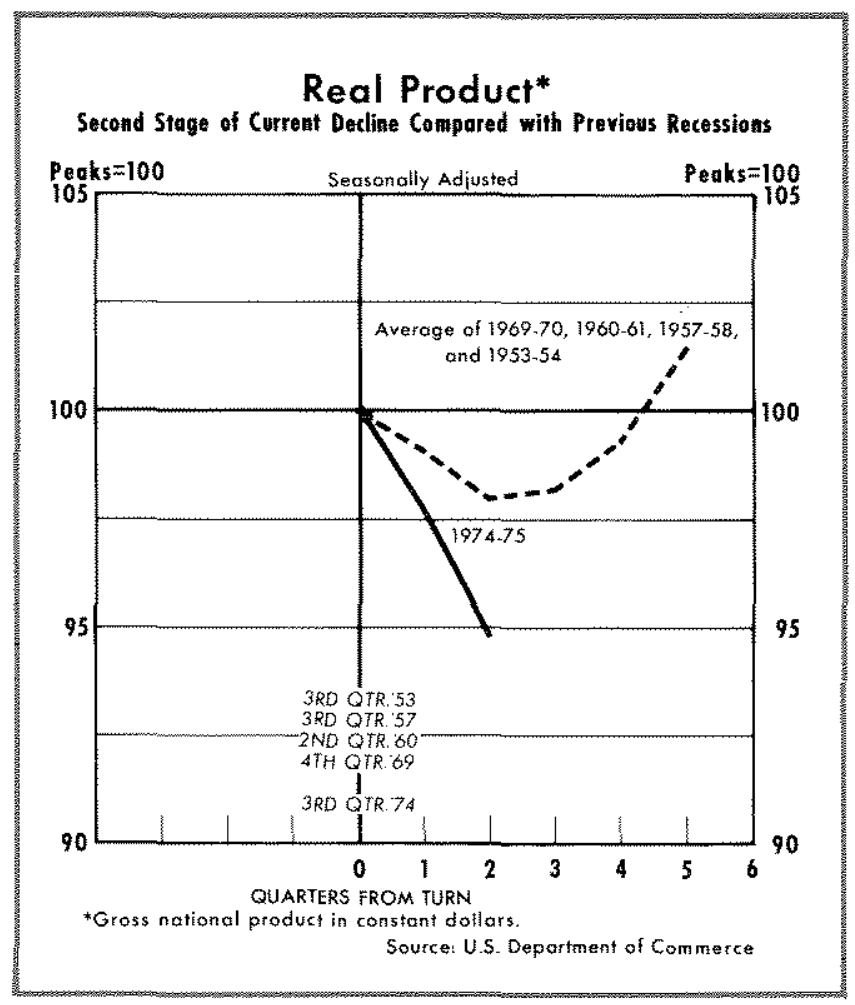




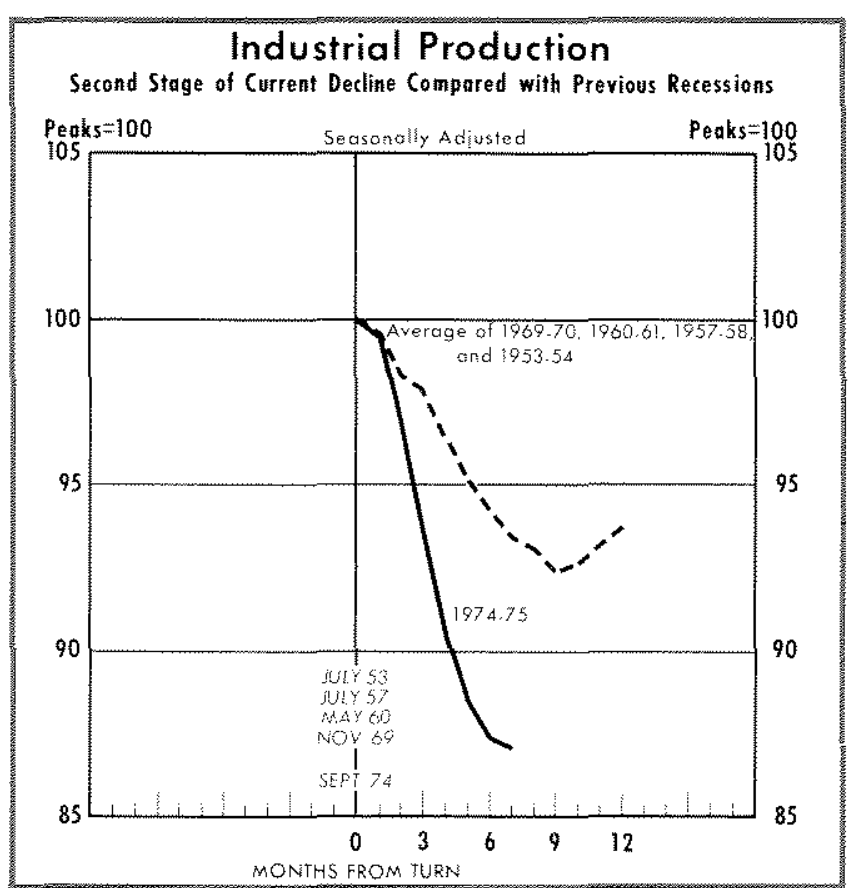

peaks, demand growth decelerated nearly the same amount, averaging a drop of 6 percentage points.

\section{Production, Employment, and Prices}

Total real output of goods and services fell at a 10 percent annual rate from the third quarter of 1974 to the first quarter of 1975. In the first two quarters of the four earlier recessions, real output declined at an average 4 percent rate. Industrial production dropped at a 21 percent rate from September 1974 to April 1975, compared with an average 11 percent rate in the first seven months of the earlier recessions. Total employment declined at a 6 percent rate from September to April, whereas it decreased at an average 2 percent rate in the comparable earlier periods.

Prices continued to rise rapidly for a time after the second stage of the recession began, the rate of increase has now slowed. From September to November 1974, consumer prices rose at a rapid 12 percent annual rate, about the same pace as in the first stage. Then, from November to April 1975 prices rose at a reduced 7 percent rate. In the earlier recessions, increases in consumer prices decelerated less than two percentage points at the seventh month, on average. The greater and quicker reduction in the rate of inflation in the second stage than in earlier recessions reflects the greater severity of the current economic decline, some dampening price effects from the first stage recession, and a dissipation of the short-run price effects resulting from removal of wage-price

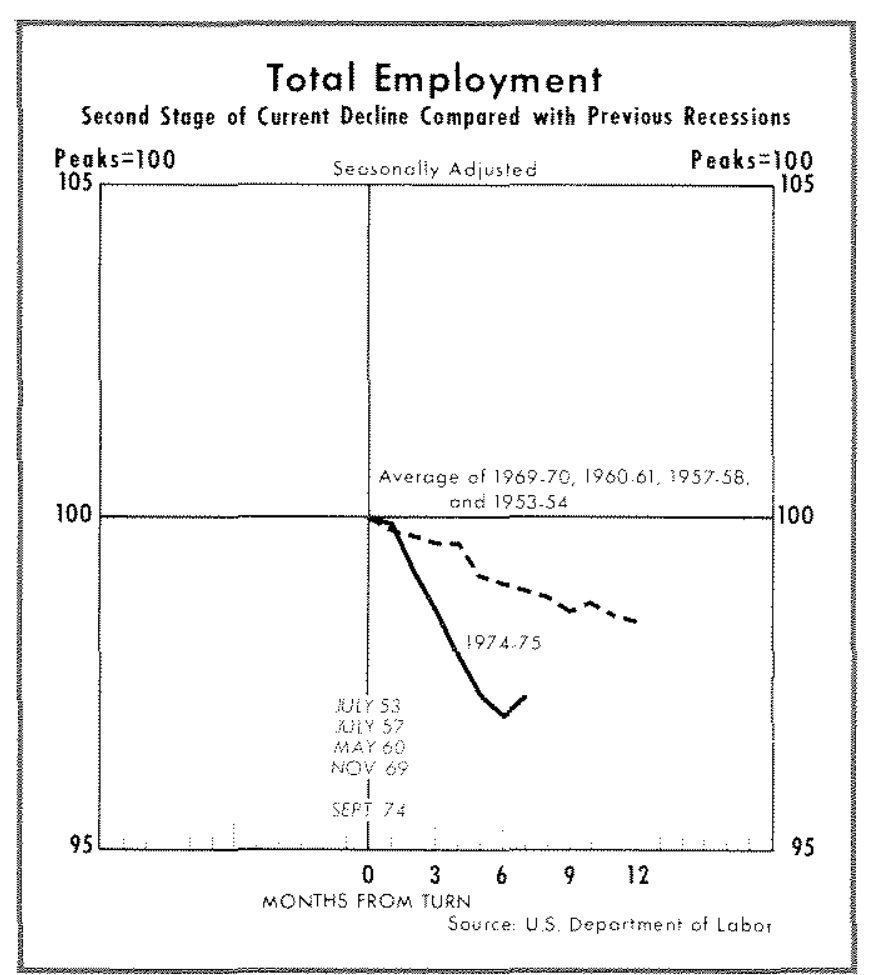

controls, the dollar devaluation, and the markup of oil prices.

\section{SUMMART AND CONCLUSTONS}

The current recession has been severe by post World War II standards, with output contracting by a greater magnitude and for a longer period than in any of the four previous recessions experienced since 1950. Not only has the current contraction been deep and prolonged, but it has been, in effect, two recessions. The first, induced largely by constraints on supply, had characteristics which differ strikingly from prior experience.

Previous recessions were preceded, and accompanied for a time, by a slow (relative to trend) rate of money growth. By contrast, money expansion in the current cycle continued to be rapid, except for a brief period, through the first two quarters of the recession. However, from the second quarter of 1974 to the first quarter of this year, the rate of money growth slowed markedly. Fiscal actions, on the other hand, have been expansive since a quarter before the current cyclical peak.

Total spending for goods and services rose substantially during the first three quarters of the current recession, pausing only moderately after the cyclical peak. However, spending growth slowed significantly 
after the third quarter of the contraction, causing the recession to enter the second stage.

Until last fall, the chief cause of the downturn came from the supply side. The nation's ability to produce was reduced by increased energy costs, unfavorable weather, costs of environmental and safety programs, the impact of dollar devaluation, and the effects of price controls. The quantity of goods and services available for consumption thus declined. Much of the current recession and the persistence of inflation have reflected the process of adjustment that the economy has been making to the constraints placed on production.

Recovery from the current recession depends on the overcoming or removal of constraints on supply. Elimination of wage and price controls was a significant step in attaining greater output, since produc- tion tends to expand when profits are enhanced. With normal weather, agricultural production should increase, placing downward pressures on the price of food. While some adjustment to the higher cost of fuel has taken place, a full adjustment will take additional time.

Economic recovery is also dependent on a pick-up in demand growth. In view of the projected sizable Federal deficits, and the probable monetary creation that will occur in financing them, total demand is likely to receive a substantial boost from fiscal and monetary developments in the near future. Since Janwary the money stock has again risen sharply. Expansionary developments are now welcome, because demand is inadequate. Yet, a stimulation of demand in excess of the ability of the economy to produce would likely result in a re-intensification of inflationary pressures at a later date.

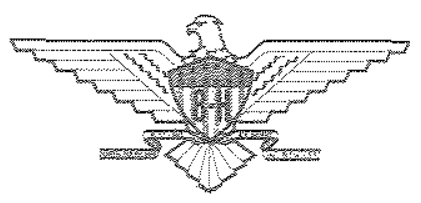

